\title{
Občanská věda: její význam a motivace účastníků v návaznosti na projekt City Nature Challenge
}

\author{
Citizen science: its importance and motivation of participants \\ in context of the City Nature Challenge project
}

\section{Petra Caltová ${ }^{1, *}$, František Tymr $^{2}$, Zdeňka Kulhavá $^{3} \&$ Vojtěch Tláskal $^{4}$}

\author{
${ }^{1}$ Národní muzeum, Cirkusová 1740, 19300 Praha 9; petra.caltova@nm.cz \\ ${ }^{2}$ Národní muzeum, Vinohradská 1, 11000 Praha 1; frantisek.tymr@nm.cz \\ 3 Jilemnická 1223, 51251 Lomnice nad Popelkou; zdenka.kulhava@gmail.com \\ ${ }^{4}$ Př́rodovědecká fakulta, Univerzita Karlova, Albertov 6, 12844 Praha 2; vojtech.tlaskal@natur.cuni.cz \\ * corresponding author
}

Caltová P., Tymr F., Kulhavá Z. \& Tláskal V., 2020: Občanská věda: její význam a motivace účastníků v návaznosti na projekt City Nature Challenge. - Journal of the National Museum (Prague), Natural History Series 189: 49-64.

\begin{abstract}
Abstrakt: Předkládaná studie pojednává o významu občanské vědy, jakožto formy vědeckého výzkumu za účasti laické veřejnosti. Podstatným, i když do dnešní doby relativně málo studovaným faktorem ovlivňujícím úspěšnost těchto projektů, je motivace účastníků. Studie se na základě výsledků dotazníkového šetření ( $n=94)$ snaží nastínit problematiku motivace a zapojení široké veřejnosti, a to na příkladu občanskovědního projektu City Nature Challenge: Praha s využitím mobilní aplikace iNaturalist. Výsledky studie ukazují, že účastníci projektu vidí jeho význam v mapování živé přírody ve spolupráci s veřejností a zároveň v popularizaci městské biodiverzity i nutnosti její ochrany. Je patrné, že okolo projektu City Nature Challenge vzniká stabilní komunita zájemců o přírodu, kterou je potřeba motivovat odpovídajícím způsobem a dále studovat možnosti její motivace a změny v jejím chování a postojích.
\end{abstract}

Abstract: The present study discusses the importance of citizen science as a form of scientific research, defined by the participation of the general public. An important factor influencing the success of these projects, although still little studied, is the participants' motivation. Based on the results of a questionnaire survey $(n=94)$, the study tries to outline the issues of motivation and involvement of the general public on the example of citizen science project City Nature Challenge: Prague, which uses the mobile application iNaturalist. The results of the study show that the project participants see its importance in mapping wildlife in collaboration with the public, and at the same time in popularizing urban biodiversity and the need for its protection.. It is obvious that a stable community of volunteers interested in nature are emerging around the City Nature Challenge project. We need this community to be properly motivated and further studied in terms of positive motivation, changes in behavior and attitudes.

Klíčová slova: občanská věda, iNaturalist, diverzita, biomonitoring, dobrovolnictví, mobilní aplikace, City Nature Challenge

Keywords: citizen science, iNaturalist, biodiversity, biomonitoring, volunteering, mobile app, City Nature Challenge

Received: July 29, 2020 | Accepted: October 12, 2020 | Published on-line: November 18, 2020 


\section{Občanská věda}

Silvertown (2009) definoval občanskou vědu jako proces, kdy nevědečtí dobrovolníci sbírají a/nebo zpracovávají data v rámci vědeckého výzkumu. Podle definice Evropské asociace občanské vědy (ESCA 2020) existuje řada způsobů zapojení veřejnosti do vědeckého výzkumu. Obecně lze za občanskou vědu považovat spolupráci široké veřejnosti s vědeckou komunitou (Bäckstrand 2003), a to ve čtyřech úrovních zapojení účastníků (Haklay 2013):

- crowdsourcing: účastníci sbírají data bez nutných odborných znalostí

- s přispěním veřejnosti: účastníci se po základním zaškolení podílejí na sběru dat a jejich základním vyhodnocování

- se spoluúčastí veřejnosti: účastníci se podílí na definování hypotézy, sběru dat a vyhodnocení pod odborným vedením

- s úplným zapojením veřejnosti: účastníci jsou rovnocennými partnery vědeckých pracovníků. Plně se podílejí na všech úrovních vědeckého bádání.

V oblasti přírodních věd je občanská věda stále častější formou sběru dat jak ve světě (Cohn 2008, Silvertown 2009, Pocock a kol. 2017), tak v České republice (Diblíková a kol. 2018, Duží a kol. 2019, Ožana a kol. 2019). Projekty občanské vědy se staly již zavedenou formou v oblastech monitoringu biodiverzity (Devictor a kol. 2010, Trojan a kol. 2019), populačních trendů (Cannon a kol. 2005, Gardiner a kol. 2012, Adamík a kol. 2019), rozšíření invazivních druhů (Pocock a kol. 2017), návrhů managementů ekosystémů (Jordan a kol. 2016), vlivu člověka na přírodní společenstva (Stelle 2017) či monitoringu kvality životního prostředí (Njue a kol. 2019).

Významným cílem projektů občanské vědy je kromě získávání nových vědeckých poznatků také vzdělávání veřejnosti (Bonney a kol. 2009, Dickinson a kol. 2012, Ballard a kol. 2017, Trojan a kol. 2019). Mnohé studie popisují u účastníků zlepšení znalostí v oblasti přírodních věd, pochopení vědeckých postupů nebo dokonce změny v jejich chování na základě nabytých poznatků a zkušeností (Ballard a kol. 2017; Hsu a kol. 2019, López Redondo a kol. 2018). Podle Makuch a kol. (2020) jsou účastníci těchto projektů převážně ženy s vysokoškolským vzděláním. Projekty občanské vědy se však postupně zaměřují na širší spektrum cílových skupin, kterými jsou děti, mládež nebo senioři (Makuch a kol. 2020, López Redondo a kol. 2018, Tuckett a kol. 2018, Frigerio a kol. 2019). Tomu odpovídá i nastavení těchto projektů tak, aby byly pro vybrané cílové skupiny motivující a zároveň jim srozumitelné, s odpovídající náročností.

\section{Občanská věda ve vzdělávání}

Z hlediska školního vzdělávání a vzdělávání mládeže prostřednictvím projektů občanské vědy je žádoucí, podporovat novou generaci v zájmu o participaci na vědeckých projektech, a získat tak čím dál tím více obeznámených občanských vědců pro budoucí aktivity (Makuch \& Aczel 2020). Podle López Redondo a kol. (2018) je nezbytné zajistit větší flexibilitu vzdělávacího systému. Iniciátorem takové změny by měly být univerzity. Právě absolventi vysokých škol pak vedou výuku a rozhodují o jejím pojetí. Zároveň je potřeba zasáhnout systémově a podporovat praktické vzdělávání, kterému se nedostává ve školní výuce př́liš prostoru. V českém školském systému je z tohoto hlediska podporováno projektové a problémové vyučování, které v kombinaci se zařazením průřezových témat praktické vyučování umožňuje. Problematickou však zůstává hodinová dotace (RVP G 2016, RVP ZV 2017). V tomto rámci se občanská věda rodí jako forma demokratické účasti veřejnosti ve vědě, v níž jsou občané aktivní součástí vědeckého projektu. Působí jako most mezi odborným vzděláváním a laickou participací. Kromě získávání nových znalostí a vědeckých dovedností, podporuje také změnu přístupu k vědě samotné. Je prokázáno, že interakce s životním prostředím v dětském věku pomáhá zlepšovat dovednosti, jako je tvořivost a řešení problémů, a pozitivně ovlivňovat emoční a intelektuální rozvoj. Adolescenti, kteří se účastnili projektů občanské vědy, disponují větším porozuměním vědeckým konceptům, zlepšují se ve vzájemné spolupráci 
a schopnosti řešit konflikty, roste jejich sebeúcta a pozitivně se proměňuje i chování ve tř́́dě (López Redondo a kol. 2018).

V roce 2007 byl v Chile realizován úspěšný projekt občanské vědy „Národní odběr vzorků malých plastových nečistot“ pro děti od 8 do 16 let (Makuch a kol. 2020). Projekty občanské vědy je možné vhodnými nástroji přizpůsobit k zapojení široké veřejnosti bez ohledu na velikost regionu nebo znalosti a schopnosti účastníků. Př́kladem může být projekt konaný v JAR, který byl postaven na práci se speciálním softwarem „CyberTracker“ verze 3.507. S využitím piktogramů se do projektu mohli zapojit i negramotní lidé, což se v této oblasti netýkalo jen dětí (Makuch \& Aczel 2020). Na Západoaustralské univerzitě se studenti biologie zúčastnili občanskovědního programu ClimateWatch zaměřeného na sběr fenologických údajů o rostlinách a zvířatech (Mitchell a kol. 2017).

\section{Možnosti občanské vědy}

Projekty občanské vědy se u veřejnosti stávají stále populárnější, a to především u zájemců o prrírodu či environmentální trendy a problémy (Cohn 2008). Díky tomu se občanská věda stala významným nástrojem popularizace vědy. Účastníci mají možnost se zapojit do samotného výzkumu, jednotlivých procesů, setkat se s možnými úskalími a pochopit tak alespoň částečně význam podobných projektů a potřebu jejich financování (Silvertown 2009). Silnou stránkou dnešní doby je existence moderních technologií, které jsou využívány napříč různorodými projekty občanské vědy. Nejen že ji tyto technologie zpřístupňují stále širšímu publiku (Devisch \& Veestraeten 2013), ale také ulehčují sběr dat a umožňují vědcům zpracovávat stále větší množství informací. Zároveň nabízejí možnosti užší komunikace jak se stávajícími, tak s potenciálními účastníky projektu (Silvertown 2009, Bonney a kol. 2014). Zapojením vysokého počtu účastníků jsou projekty občanské vědy schopny dlouhodobě získávat značné množství dat z velkého geografického území, díky čemuž je možné sledovat např. populační trendy. Také se zvyšuje pravděpodobnost zachycení neobvyklých pozorování nebo krátkodobých jevů, které by se svou omezenou možností terénního výzkumu nebyla vědecká komunita schopna zaznamenat (Dickinson a kol. 2012, Pocock a kol. 2014). Vzhledem k dobrovolnické povaze těchto projektů se výrazně snižují náklady na výzkum (Silvertown 2009), na druhou stranu je potřeba počítat s výdaji v rámci propagace samotného projektu, zaškolení a další komunikace s účastníky (Frigerio a kol. 2018). Ačkoliv v poslední době přibývají projekty občanské vědy, nemusí jejich výsledky být nezbytně akceptovány vědeckou komunitou, a to především kvůli nedůvěře v jejich kvalitu a spolehlivost (Lukyanenko 2016, Bonney a kol. 2014, Johnson a kol. 2020). Vzhledem k rozdílné úrovni odbornosti jednotlivých účastníků může docházet např ke špatné determinaci (Gardiner a kol. 2012) a především k nekonzistentnosti dat (Johnson a kol. 2020). Jak ale ukazují studie mnoha autorů, ve vybraných oblastech výzkumu se práce s výsledky občanskovědních projektů stává stále častější uznávanou formou sběru dat (Pocock a kol. 2017, Stelle 2017, Diblíková a kol. 2018, Adamík a kol. 2019).

V poslední době je díky snadnému přístupu k mobilním technologiím, součástí dat také fotografická nebo akustická dokumentace. Problémem těchto dat může být nedostatečné ošetření licencí k užití (Adriaens a kol. 2015, Groom a kol. 2016). Podle Kosmalaové a kol. (2016) mohou účastníci poskytnout data stejné kvality jako profesionální vědci. Výsledek se silně odvíjí od zvoleného designu projektu (McKinley a kol. 2019) a složitosti konkrétních úkonů. Pocock a kol. (2014) uvádí, že se jednoduše nastavené projekty vyznačují větší efektivitou ve srovnání s projekty obsahujícími pro amatéry složité úkony.

Ačkoliv se může zdát, že občanská věda je novou oblastí využívanou až v posledních letech, opak je pravdou (Eitzel a kol. 2017). Projekty spojující práci vědecké a laické veřejnosti nejsou žádnou novinkou, jen byly (nebo jsou) nazývány jinak. Př́kladem je dobrovolnické kroužkování ptáků v České republice (Cepák a kol. 2008; obr. 9). První kroužkovatelé sbírali svá data již v roce 1934 při založení Kroužkovací stanice Národního muzea. V této tradici se pokračuje nepřetržitě dodnes, kdy se každoročně zapojují stovky dobrovolníků, díky nimž získávají vědečtí pracovníci enormní množství dat. Za zmínku stojí další projekty, které vznikly v České republice v posledních letech: mobilní aplikace Dragonfly Hunter CZ mapu- 
jící vážky České republiky (Ožana a kol. 2019), akustický monitoring plchů velkých (Adamík a kol. 2019) nebo strnadů obecných (Diblíková a kol. 2018). Nejnovějším počinem je projekt "Hledejte pražské motýly", který k monitoringu využívá mobilní aplikaci iNaturalist.

\section{Využití moderních technologií}

Moderní technologie představují nové možnosti zapojení široké veřejnosti do projektů občanské vědy. Využití internetu a chytrých telefonů s mobilními aplikacemi snižuje nároky na odbornost jednotlivých účastníků (Devisch \& Veestraeten 2013) a umožňuje do projektů zapojovat i absolutní laiky. Podle Whitakerové a kol. (2014) je využití těchto technologií pro získávání dat v př́rodních vědách významným pomocníkem, vzhledem k zapojení jak amatérů se zájmem o environmentální otázky, tak účastníků technologicky zaměřených. Mnoho mobilních aplikací, pomocí kterých jsou sbírána data do projektů občanské vědy, pracují s prostorovými souřadnicemi, které jsou podobně jako časový údaj záznamu ukládány automaticky čipem GNSS. Zapojení GNSS významně snižuje chybovost a zároveň usnadňuje verifikaci dat (Adriaens a kol. 2015).

\section{Aplikace iNaturalist}

V roce 2008 vznikla v USA mobilní aplikace iNaturalist (Nugent 2008). Jedná se o jednu z největších databází zaměřenou na získávání přírodovědných pozorování (Boone \& Basille 2019), kterou používá více než milion uživatelů z řad přírodovědcủ i široké veřejnosti po celém světě $\mathrm{k}$ focení živé přírody. Aplikace je prostřednictvím algoritmické neuronové sítě schopna podle fotografie a polohových souřadnic pozorování nabídnout určení druhu (Altrudi 2020), přičemž je úspěšnost určení u běžných druhů až 97,3 \% (Unger a kol. 2020). Primárním cílem aplikace je vzbudit u veřejnosti zájem o př́rodu. iNaturalist funguje také jako sociální sít', kde lidé sdílí informace o výskytu druhů a vzájemně si pomáhají učit se o prrírodě více (iNaturalist 2016). Druhým cílem aplikace je získávání vědecky hodnotných dat. Veškerá pozorování, která obsahují povinná data (fotografii,

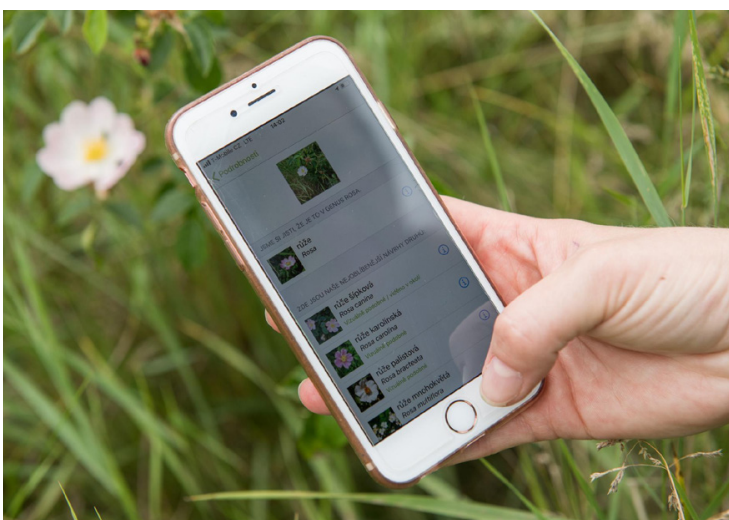

Obr. 1: Mobilní aplikace iNaturalist nabízí určení pozorovaného druhu podle fotografie a zeměpisných souřadnic. Foto: V. Lukáš. datum a lokaci pozorování) a jejich určení je ověřeno dvěma a více uživateli, se stávají součástí celosvětové databáze biodiverzity GBIF (Global Biodiversity Information Facility) (Altrudi 2020, Johnson a kol. 2020). Postupem času se aplikace stala jedním z významných, dlouhodobých zdrojů dat (Hobson a kol. 2017). Díky tomu, že aplikaci používají denně desítky tisíc uživatelů po celém světě, se nezřídka stává, že jsou pozorovány vzácné druhy, které by jinak místním prrírodovědcům unikly. Př́kladem může být endemický druh čmeláka na Filipínách. Ten byl pozorován po 25 letech od posledního zaznamenaného výskytu právě pomocí aplikace iNaturalist (Wilson a kol. 2020). V množství př́rodovědecky zaměřených pracích využívají autoři data z aplikace jako doplňující zdroj informací k vlastnímu výzkumu (Adamík a kol. 2019, Moore et al 2019). V poslední době je stále zřejmější, že s její pomocí je možné získat data nejen o výskytu a početnosti konkrétních druhů, ale také o jejich vzájemných interakcích, jak uvádí Gazdic \& Groom (2019) v př́ípadě kombinovaných pozorování vybraných druhů hmyzu a rostlin. 
Limitou aplikace iNaturalist se může zdát možnost špatné determinace, uložení nekvalitních pozorování nebo použitelnost pouze dat tzv. výzkumného stupně. Oproti tomu Hochmair a kol. (2020) při porovnání různě kvalitních pozorování termitů uložených do aplikace uvádějí možnost použití celého datasetu bez vlivu na kvalitu výsledného výstupu.

Za nutné považujeme zmínit jedinečnou vlastnost aplikace, a to možnost vytváření vlastních projektů. Toho využívají nejen pedagogové, ale také množství organizací zaměřených na environmentální vzdělávání, výchovu a osvětu (Schade a kol. 2019, Hernawati a kol. 2020).

\section{Monitoring městské přírody}

Mobilní aplikace iNaturalist je užitečným nástrojem, pro který je potřeba vytvořit odpovídající projekty občanské vědy. V roce 2016 vznikl v USA projekt s názvem City Nature Challenge (dále jen CNC). Původně se jednalo o přátelské klání dvou měst, které organizovalo Přrírodovědecké muzeum v Los Angeles a Kalifornská univerzita. Dnes se jedná o tradiční celosvětovou událost, jejímž cílem je seznámit obyvatele velkých měst $\mathrm{s}$ místní př́rodou. $\mathrm{V}$ průběhu soutěžních dní se snaží účastníci sesbírat co největší počet pozorování pomocí aplikace iNaturalist. Součástí projektu jsou doprovodné programy $\mathrm{v}$ podobě komentovaných exkurzí, workshopů, přednášek nebo akcí pro rodiny s dětmi (DITOs consortium 2019).

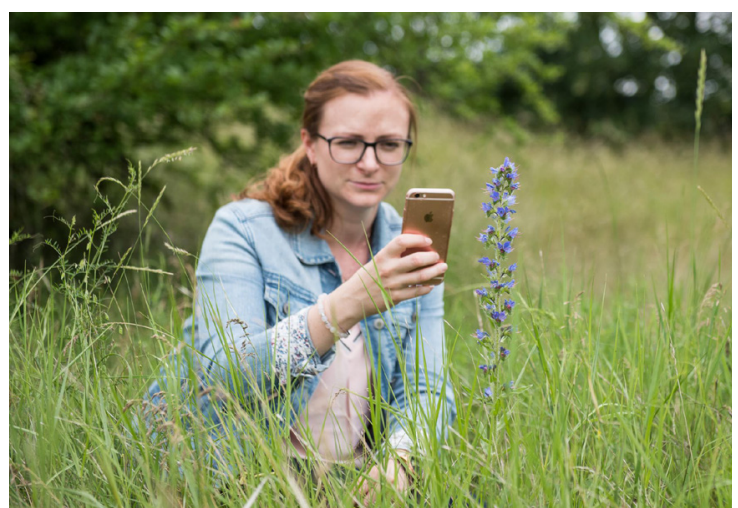

Obr. 2: Sběr dat mobilní aplikací iNaturalist. Foto: V. Lukáš. Projekt rychle získal na oblibě a rozšíril se do měst celého světa s aktuálním počtem více než 200 zapojených měst (CNC 2020). Výsledky každoročního projektu se zaměřují na výskyt invazivních a ohrožených druhů a dokumentaci biodiverzity. Leong \& Trautwein (2019) využili kladné stránky projektu, resp. ukládání relativně velkého množství dat získaného v omezeném čase na předem určeném území, a studovali biotickou homogenizaci ve 14 metropolitních městech USA.

I v České republice se stává projekt CNC tradiční akcí, do které se zapojuje stále více účastníků (Macek \& Caltová 2019). Vzniká tak stálá komunita zájemců o přírodu a environmentální problematiku v obou městech, která se aktuálně do projektu zapojila, a to v Praze a Brně. Komunikace s touto cílovou skupinou probíhá celoročně skrz sociální sítě a webové stránky projektu, organizovány jsou aktivity v průběhu celé vegetační sezóny.

\section{Motivace účastníků}

Vzhledem k tomu, že jsou projekty občanské vědy postaveny na spolupráci s dobrovolníky, je klíčové zaměřit se právě na jejich motivaci, bez které brzy opadne jejich zájem podílet se na projektu (Maund a kol. 2020). Proto je více než žádoucí zabývat se hlouběji studiem profilů jednotlivých účastníků, jejich motivace, postojů a očekávání (Ganzevoort a kol. 2020). López Redondo a kol. (2018) uvádí, že jsou při rozvíjení vědeckých poznatků v projektech občanské vědy nejvýznamnější dva faktory: motivace a zájem účastníků; interakce mezi profesionálními vědci a občany. Jejich studie potvrdila, že při komunikaci mezi výzkumnými pracovníky a dobrovolníky byl patrný zájem účastníků o aspekty vědecké metody, vlastní pozorování a závěry. Dalším mimořádně pozitivním důsledkem byla změna postoje účastníků na projek- 
tech občanské vědy k vědě samotné. Bylo prokázáno, že ke změnám postojů dochází o to intenzivněji, čím větší znalostí problematiky účastníci disponují. Podobně uvádí Falk (2001), že se motivace široké veřejnosti zvyšuje, pokud se vědecký výzkum týká jejího bezprostředního okolí, je součástí jejího životního prostředí nebo se jí přímo dotýká. Zároveň podle Pocock a kol. (2014) jsou účastníci projektu ochotnější provádět i složitější úkony, pokud v zapojení a vědecké práci vidí význam. Navíc spokojení (dobře motivovaní) účastníci často šírí své pozitivní zkušenosti s projektem a pomáhají tak rozšiřovat komunitu zainteresovaných dobrovolníků (Maund a kol. 2020). Ačkoliv je motivace významným faktorem úspěšnosti projektů občanské vědy (Tweddle a kol. 2012), existuje aktuálně relativně malý počet studií, které se zabývají tímto tématem. Follet \& Strezov (2015) uvádějí, že pouhá 3 \% studií projektů zabývajících se občanskou vědou byla zaměřena na motivaci účastníků. Bruyere \& Rappe (2007) či Admiraal a kol. (2017) určili jako klíčové motivace možnost spojení s př́írodou a snahu pomoci, získávání nových znalostí a př́ležitost další socializace, at' už v rámci spolupráce s rodinnými př́slušníky a přáteli nebo v komunitě cizích lidí se stejnými zájmy. Motivaci upevňuje také pravidelná komunikace a dialog s účastníky, možnost sledovat zajímavosti o aktuálním postupu, průběžné výsledky a změny v reálném čase. Díky internetu a moderním technologiím je podobná komunikace s účastníky stále jednodušší (Bonney a kol. 2009, Tweddle a kol. 2012).

Předkládaná studie si klade za cíl zmapovat profily účastníků projektu občanské vědy CNC v České republice na základě užívání aplikace iNaturalist.

\section{Metodika}

Při sběru dat byla zvolena metoda kvantitativního výzkumu formou dotazníkového šetření. Z metodologického hlediska patří kvantitativní výzkum k často užívaným metodám v oblasti př́rodních věd. Výhodou této metody je reliabilita dat, možnost realizace výzkumu v krátkém časovém úseku a vyjádření výsledků formou čísel. Tato numerická data umožňují jak srovnání mezi organizacemi nebo skupinami, tak určení rozsahu shody nebo neshody respondentů. Efektivní kvantitativní výzkum obvykle vyžaduje velké množství vzorků, kvůli čemuž musí být často vynaloženy značné prostředky. Slabinou této metody je nemožnost významnějšího kontaktu s respondentem, a také hloubka problematiky, do níž může výzkumník proniknout. Ta je oproti tomu doménou kvalitativní formy výzkumu, kdy má výzkumník možnost dlouhodobé spolupráce $s$ respondentem, což je zároveň často kritizováno právě kvůli hledisku zachování míry objektivity (Choy 2014).

Cílovou skupinou výzkumu byli uživatelé aplikace iNaturalist v Praze a v Brně, bez ohledu na jazykové a demografické charakteristiky nebo úroveň vzdělání. Účastníci byli osloveni online přes aplikaci iNaturalist s žádostí o vyplnění krátkého anonymního dotazníku vytvořeného v Google formuláři. Pojetím kvantitativního výzkumu jsou $\mathrm{v}$ př́padě na-

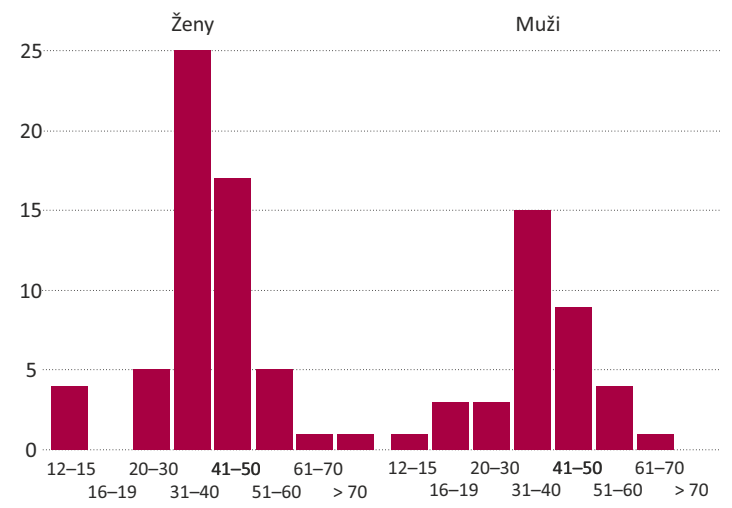

Obr. 3. Rozložení věku respondentů pro ženy a muže. šeho šetření polostrukturované dotazníky obsahující jak standardizované, tak otevřené otázky. Dotazník obsahoval 24 otázek, z toho se 6 týkalo sběru demografických dat, aby byl získán přehled o respondentech. Pouze tři otázky vyžadovaly otevřenou odpověd'. V př́ípadě ostatních otázek se jednalo o výběr z možností (ano x ne; 
škála rozhodně ano až po rozhodně ne; otázky, které umožňovaly označení více možností). Výsledky dotazníkových odpovědí byly po jednom měsíci staženy z aplikace Google formuláře a vyhodnoceny. Poměry odpovědí byly spočítány v programu R 4.0.0 pomocí balíčku tidyverse 1.3.0, grafy byly vytvořeny v balíčku ggplot 3.3.1. Data z pozorovací kampaně CNC byla stažena pomocí exportovací aplikace na stránkách iNaturalist po zadání projektu CNC 2020 Praha a Brno. Globální údaje o CNC byly získány od zahraničních koordinátorů projektu.

\section{Výsledky}

\section{Všichni respondenti}

Celkem bylo osloveno 1045 uživatelů používajících mobilní aplikaci iNaturalist na území Prahy a Brna. Dotazník byl zaslán účastníkům všech ročníků CNC v České republice a zároveň uživatelům, kteří ukládali svá pozorování na území hlavního města nehledě na účast v projektu CNC. Vyplnilo jej 94 z nich (resp. 8,99\% oslovených). Nízká návratnost dotazníků je dána pravděpodobně oslovením široké komunity uživatelů bez ohledu na to, zda jsou stálými uživateli aplikace či nikoliv.

Mezi respondenty převažovaly ženy, které vyplnily 62 \% dotazníků (obr. 3). Nejvíce dotazovaných (42\%) spadalo do věkového rozpětí 31-40 let, následováno účastníky ve věku 41-50 let (28 \%). Ostatní věkové skupiny byly zastoupeny pod $10 \%$, nejmladším respondentům bylo 12-15 let, nejstaršímu přes 71 let.

Nejčastějšími pozorovateli, kteří často a pravidelně přispívají do aplikace ukládáním vlastních pozorování, jsou totožné dominantní věkové skupiny (obr. 4A). Determinaci jednotlivých pozorování provádějí majoritně uživatelé aplikace ve věkovém rozpětí 41-50 let (obr. 4B).

Většina dotazovaných (78 \%) je pracujících (obr. 5) s vysokoškolským vzděláním (67 \%). Přičemž získaná úroveň vzdělání se genderově nelišila.

Co se týče délky využívání aplikace, 37 \% respondentů uvedlo, že ji využívá méně než jeden měsíc (23 \% z Prahy a 4 \% z Brna, ostatní město neuvedli). 33 \% respondentů pracuje s aplikací 1-3 roky (obr. 6). Polovina dotazovaných uvedla, že si aplikaci nainstalovala, protože se zapojila do projektu CNC. To potvrzuje silnou provázanost aplikace a projektu CNC, který mimo jiné funguje jako popularizace samotné aplikace.

Hlavní otázky cílily na motivaci účastníků k využívání apli-
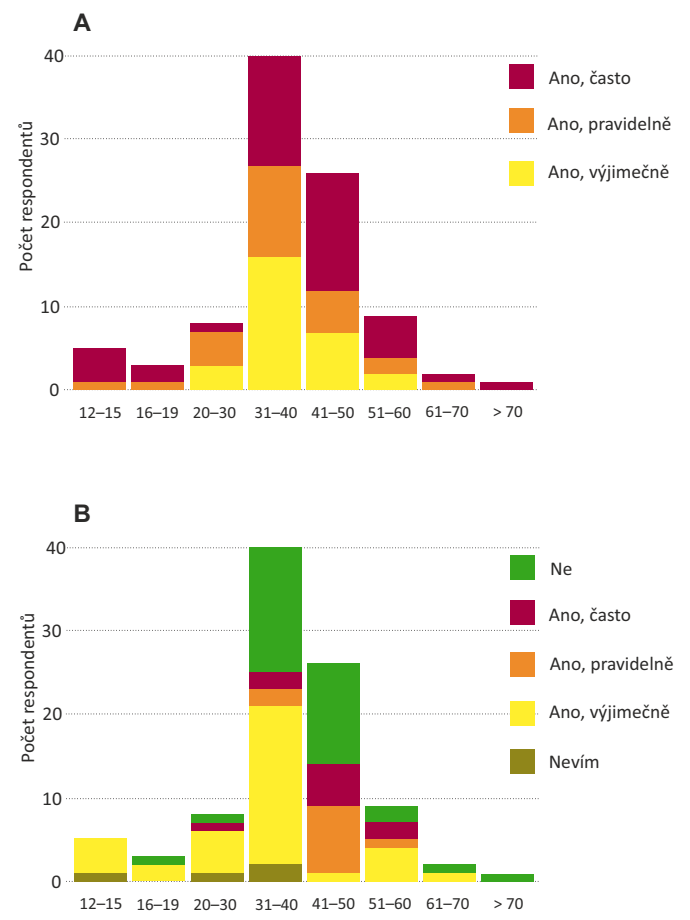

Obr. 4. Počet pozorovatelů $(A)$ a určovatelů $(B)$ v závislosti na věku a intenzitě práce $s$ databází iNaturalist. Otázka pro intenzitu nahrávání pozorování zněla: Nahráváte do aplikace vlastní pozorování? Otázka pro intenzitu určování zněla: Identifikujete v aplikaci pozorování ostatních uživatelů? 
kace a vliv jejího používání na chování respondentů (resp. zda se mění jejich vztah $\mathrm{k}$ trávení volného času v přírodě). Jako nejčastější motivaci k využívání aplikace uváděli dotázaní její schopnost určovat nalezené druhy. Dále byla uvedena možnost naučit se poznávat nové druhy organizmů. Motivace začít využívat aplikaci kvůli častějším vycházkám do prrírody se umístila $v$ pořadí na čtvrtém místě (obr. 7). 57 \% účastníků uvedlo, že při využívání aplikace vyráží sami do přírody častěji.

Většina respondentů (84 \%) znala projekt CNC před vyplněním dotazníkového šetření. $\mathrm{V}$ roce 2020 se projektu aktivně zúčastnilo $60 \%$ dotázaných. $\mathrm{Z}$ těchto účastníků byl dotazník vyplněn hlavně respondenty z Prahy (78\%), 20 \% respondentů se účastnilo v Brně, $2 \%$ respondentů otázku nezodpověděla. Vzhledem $\mathrm{k}$ tomu, že v Praze se konal již třetí ročník tohoto projektu, zkoumali jsme také, zda se respondenti projektu účastní pravidelně. Dotazovaní se v průměru zapojili do jednoho ročníku CNC. $24 \%$ respondentů aplikaci vyu-

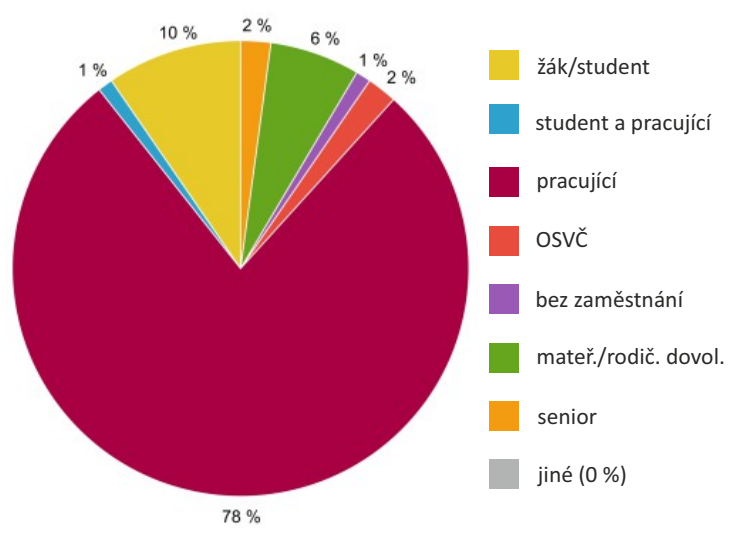

Obr. 5. Rozložení profesí respondentů.

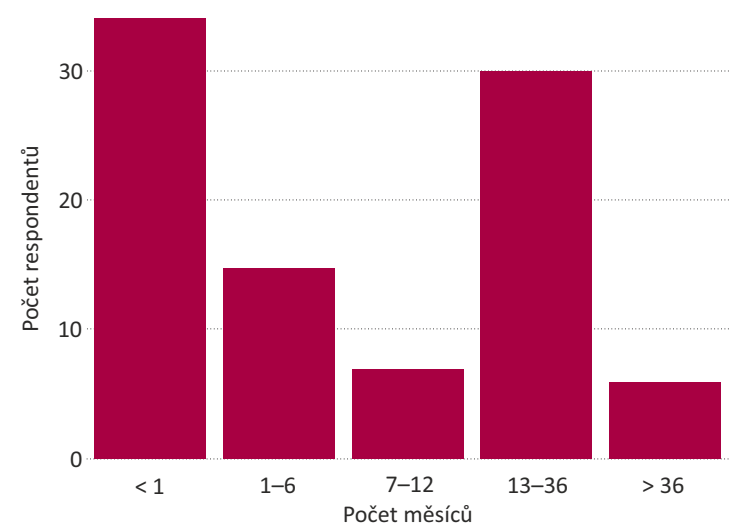

Obr. 6. Délka využívání aplikace iNaturalist respondenty. žívalo méně než měsíc a zároveň se zúčastnilo právě jednoho ročníku CNC. S největší pravděpodobností se tedy jedná o nové uživatele aplikace, kteří ji začali využívat právě v průběhu projektu CNC 2020. Jako hlavní cíl projektu vnímají respondenti mapování výskytu druhů živé př́írody za pomoci veřejnosti, což odpovídá definici projektů občanské vědy. Dalšími vnímanými cíli je zvýšení povědomí o přírodě u laické veřejnosti a popularizace ochrany přírody (obr. 8).

\section{Respondenti se známým uživatelským jménem}

Vzhledem k tomu, že projekt nabízí široké pole k dalšímu bádání, rozhodli jsme se uživatele požádat o svolení k opakovanému kontaktování spojeného s navazujícím výzkumem. Díky tomu je možné dohledat aktivitu v aplikaci iNaturalist u $62 \%$ respondentů, kteří do dotazníku uvedli svoje uživatelské jméno. Pozorování těchto uživatelů tvořila během CNC 2020 celkem 23 \% z 9220 ověřitelných pozorování v Praze a 34 \% z 2504 ověřitelných pozorování v Brně. Porovnáním uživatelských jmen s odpověd'mi v dotazníku ohledně délky využívání aplikace jsme identifikovali pozorování uživatelů - nováčků, kteří aplikaci využívají méně než měsíc. Těchto ověřitelných pozorování v rámci CNC bylo za Prahu a Brno dohromady 7 \%.

Průměrný počet pozorování jednoho respondenta se známým uživatelským jménem v projektu CNC byl $82 \pm 23$, medián byl 35. Zatímco celostátní průměr všech pozorování v rámci CNC 2020 na uživatele byl $23 \pm 2$ a medián 4. To spíše odpovídá celosvětovému prů- 
měru počtu pozorování na osobu v rámci CNC 2020 (průměrně 20 pozorování; n pozorovatelů $=41379$ ). Identifikováno a ověřeno komunitou bylo 67 \% všech pozorování v ČR od respondentů se známým uživatelským jménem. Což znamená, že tato část dat získala tzv. výzkumný stupeň a stala se součástí GBIF. Poměr pozorování na úrovni výzkumný stupeň byl pro celou Prahu $60 \%$, pro Brno $55 \%$ a celosvětový průměr $46 \% \pm 1 \%$ (n měst $=220$ ).

\section{Diskuze}

Zapojení široké veřejnosti do vědeckého bádání v rámci projektů občanské vědy je využíváno stále častěji. Pro úspěšný průběh těchto projektů je klíčová silná motivace účastníků (Sutherland a kol. 2015). Podobně jako ve výzkumu Maund a kol. (2020) proběhlo v předkládané studii dotazníkové šetření, které umožnilo prozkoumat motivaci dobrovolníků k používání aplikace iNaturalist a jejich názor na hlavní cíle projektu CNC.

I přes relativně malý vzorek vyplněných dotazníků $(n=94)$ jsme získali zajímavá data prezentující pohled účastníků na projekt i mobilní aplikaci. Podobně jako ve studii Makuch \& Aczel (2020) byly nejčastějšími účastníky ženy s vysokoškolským vzděláním. Vzhledem k využití moderních technologií by se mohlo zdát, že se do projektu zapojí především mládež a lidé do 30 let. Z výsledků ale naopak vyplývá, že hlavní kategorii respondentů tvoří pracující lidé s vysokoškolským titulem ve věkovém rozmezí 31-50 let, přičemž ostatní věkové skupiny byly zastoupeny minimálně. To je v souladu se závěry podobně zaměřených studií. Těžiště pozorovatelů se nachází ve věkovém rozmezí 31-40 let. Převaha častých a pravidelných uživatelů identifikujících pozorování je posunuta do rozmezí 41-50 let věku. Ve studii holandských autorů uvádí Ganzevoort \& Born (2020) průměrný věk účastníků občanské vědy 61,8 let. Tento rozpor je pravděpodobně daný specifickým místním sociodemografickým rámcem. Dalšími faktory ovlivňujícími složení účastníků mohou být různorodé typy projektů občanské vědy lišící se jak celkovým designem, motivací účastníků, tak především prostředky, které jsou v rámci projektů využívány.

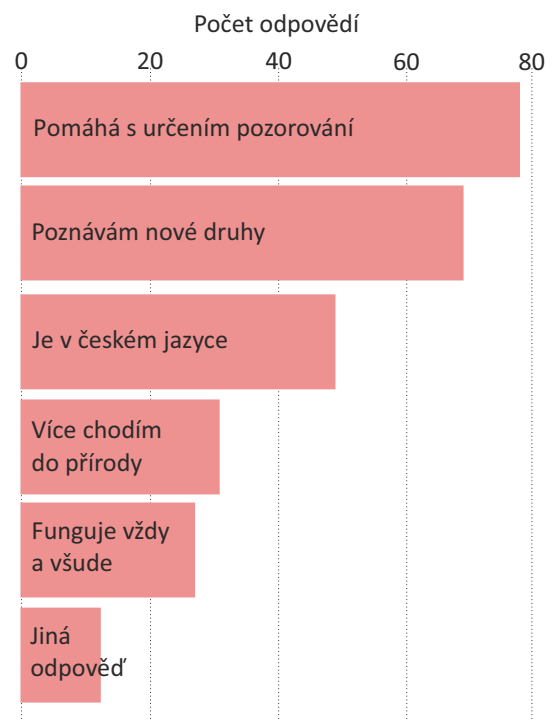

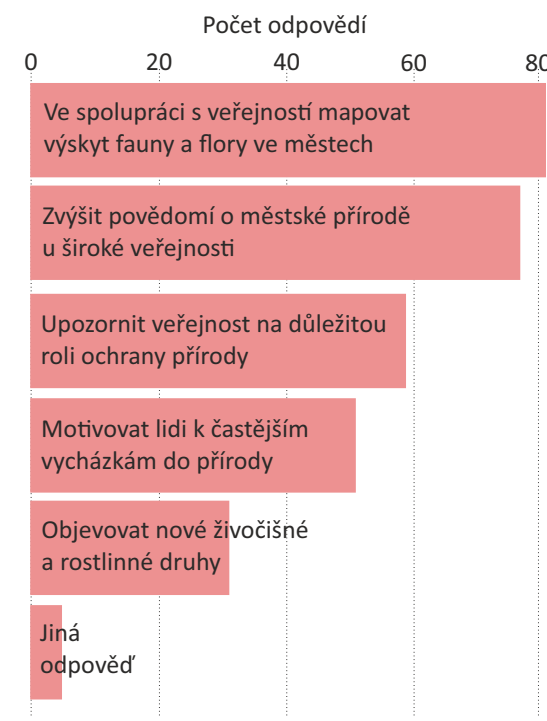

Obr. 7. Motivace respondentů k používání aplikace iNaturalist. Dotazník nabízel vyplnění více možností. Graf vyjadřuje absolutní počet všech uvedených odpovědí.

Obr. 8. Jak jsou vnímány cíle projektu City Nature Challenge v odpovědích respondentů. Dotazník nabízel vyplnění více možností. Graf vyjadřuje absolutní počet všech uvedených odpovědí. 
Nejčastější motivací pro využívání mobilní aplikace iNaturalist byla uváděna její schopnost nabídnout určení pozorovaného druhu. Respondenti také vyzdvihovali možnost naučit se poznávat prŕrodu kolem sebe a vítali překlad aplikace do českého jazyka. Dalším předmětem výzkumu bude otázka, zda aplikaci využívá spíše komunita široké veřejnosti bez hlubšího př́rodovědeckého zázemí. Zapojování této kategorie do podobných projektů bez předchozího školení usnadňuje internet a široké využívání moderních technologií (Bonney a kol. 2014, Maund a kol. 2020).

Více než polovina respondentů (57 \%) uvedla, že díky používání aplikace se vydává do přírody častěji než dřive. Ačkoliv se podle výsledků nejedná o primární motivaci účastníků, autoři předpokládají, že dochází ke změně v chování a potenciálně i návyků uživatelů aplikace. Toto zjištění podporuje výsledky studie Hsu a kol. (2019). Ti uvádějí, že zapojení do krátkodobých projektů občanské vědy významně ovlivňuje vědomosti, postoje a chování účastníků. Tato otázka bude předmětem dalšího výzkumu, kdy budou osloveni uživatelé, kteří ve stávajícím dotazníkovém šetření uvedli svoje uživatelské jméno. Nejenže se tito účastníci zapojili do dalšího možného výzkumu týkajícího se motivace účastníků projektů občanské vědy, zároveň se jedná o skupinu aktivních uživatelů aplikace, jejichž pozorování tvoří celkem $26 \%$ v projektech CNC 2020 v ČR. Tito respondenti uložili průměrně několikanásobně více pozorování ve srovnání s ostatními účastníky jak v ČR, tak celosvětově a jsou částečně zodpovědní za globálně nadprůměrné poměry českých pozorování, které získaly výzkumný stupeň. Tyto výsledky naznačují, že zde vzniká komunita zainteresovaných uživatelů, kteří jsou nakloněni dalším projektům a spolupráci. Je více než přínosné udržovat s touto komunitou kontakt a podporovat její motivaci k dalšímu zapojení (Maund a kol. 2020).

Významnou otázkou je implementace občanské vědy do školního vzdělávání. Je totiž závislá na mnoha faktorech, přičemž jedním z hlavních je opět motivace. Klíčová je primárně motivace pedagogů pro jejich zapojení do jakékoli mimoškolní aktivity. Tu mohou ovlivnit další faktory, jako je např. časová náročnost projektu, do kterého se školy zapojují, protože v mnoha ohledech vyučující odrazuje práce navíc spojená s přípravou, realizací, vyhodnocením apod. (Harlin a kol. 2018) Roli hraje samožrejmě i dostupnost aktivity. Možnost její realizace na půdě školy nebo nutnost navštívení instituce či exteriéru, a hlavně jejich dosažitelnost. Další záležitost, která se týká konkrétně CNC a aplikace iNaturalist, je také otázka technického vybavení, které žáci a jejich učitelé budou potřebovat. Ve většině případů škola stále neposkytuje žákům dostatečné technické vybavení a zázemí využitelné pro jejich práci, a pokud ano, tak

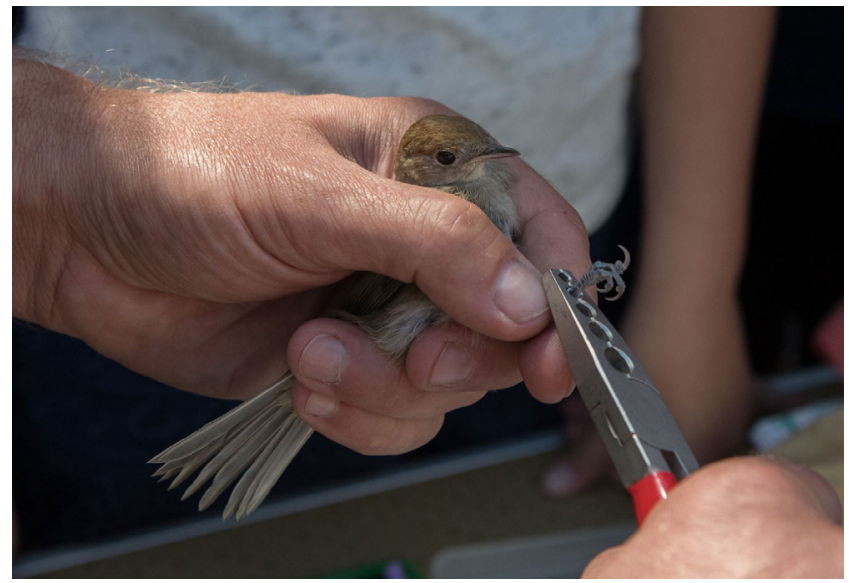

Obr. 9. Jeden z dlouhodobých projektů v České republice je kroužkování ptáků organizované Kroužkovací stanicí Národního muzea. Foto: V. Lukáš. na půdě školy, nikoli v exteriérech. A stále nelze předpokládat, že každý žák disponuje nejpozději od 6. třídy základní školy chytrým mobilním telefonem s možností připojení k internetu. V neposlední řadě, jak dokazují evaluace již realizovaných projektů občanské vědy pro školy v zahraničí, je důležité poskytnout adekvátní podporu učitelům, věnovat čas jejich proškolení a také poskytnout školám edukační a podpůrné materiály (Bonney a kol. 2014). Rámcové vzdělávací programy pro 
základní i stř̌ední vzdělávání obsahují jako průřezové téma Environmentální výchovu, jejíž mezioborovost a samotný obsah lze propojit s občanskou vědou. „Environmentální výchova představuje nezastupitelný významný předpoklad udržitelného rozvoje, jenž patř́ i mezi prvoradé zájmy Evropské unie. Základním předpokladem nastoupení cesty k udržitelnému rozvoji je zvýšení ekologického vědomí lidí a jejich odborná připravenost na kvalitativně nové prístupy $v$ celé technicko-ekonomické a sociální oblasti. $Z$ těchto důvodu se stává environmentální výchova prüřezovým tématem vzdělávání na gymnáziu a jedním ze základních pilírư vzdělávání pro udržitelný rozvoj." (RVP G 2016). Ačkoliv podle věkového rozložení respondentů dotazníku je potenciál pro využívání občanské vědy ve věkových kategoriích do 30 let stále nedostatečně využit, edukační potenciál takových projektů se netýká jen žáků základních a středních škol. Jejich vzdělávací složka je atraktivní i pro další kategorie uživatelů aplikace iNaturalist, at’ už se jedná o dospělé v produktivním

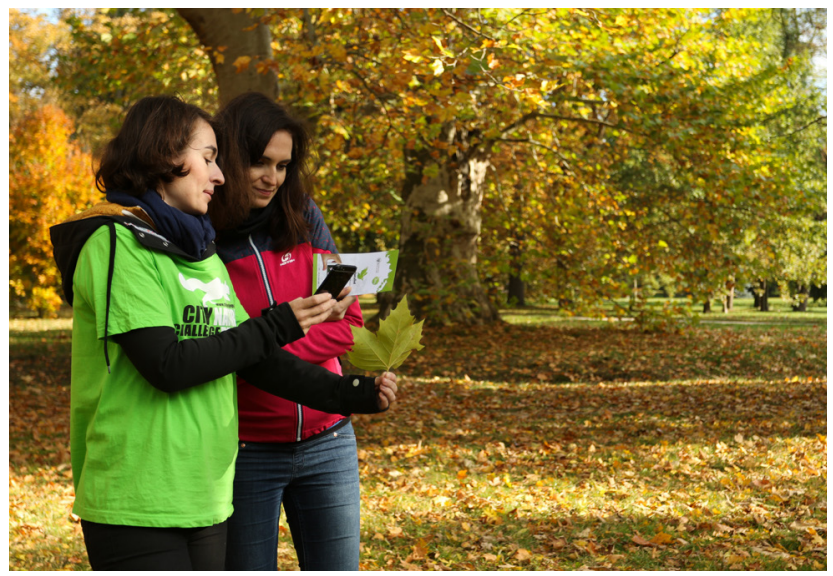

Obr. 10. Klíčovou součástí úspěšných projektů občanské vědy je vytvoření odpovídající komunikační strategie zaměřené na účastníky projektu. Foto: D. Koleška věku, rodiny s dětmi nebo seniory. V dotazníkovém šetření hned několik uživatelů aplikace iNaturalist odpovědělo, že jejich motivací k jejímu využívání je aktivní trávení času s rodinou, zadání v rámci studia na gymnáziu nebo vlastní zájem jakožto pedagoga přírodopisu. Pamětové instituce, jakými jsou např. muzea, mají velmi dobrou výchozí pozici pro spolupráci se školami a šíření osvěty občanské vědy (Ballard a kol. 2017). Na př́kladu Národního muzea lze prezentovat, jaké jsou možnosti využití projektu CNC, a s ním spjaté aplikace iNaturalist pro vzdělávání veřejnosti všech věkových kategorií, a o možnostech přispění odborníkům do jejich výzkumů skrze vlastní aktivní zapojení. Přestože je zde riziko nerovnoměrného zastoupení pozorovaných taxonů v databázích založených na př́spěvcích laické veřejnosti (Troudet a kol. 2017), je aplikace iNaturalist významným prostředkem pro popularizaci vědy, sběr dat i velmi dobrá platforma pro úspěšné projekty občanské vědy.

Již samotné nastavení projektu CNC je srozumitelné široké veřejnosti a mezinárodní soutěž je pro ni natolik motivující, že se zapojuje stále širší spektrum účastníků. Jak je uvedeno výše, klíčovou roli v úspěšných projektech občanské vědy hraje pravidelná a detailní komunikace s účastníky. To se silně projevilo v rámci letošního ročníku projektu. Kvůli neočekávané koronavirové krizi - a s tím spojeným omezením shromažd’ování veřejnosti - byla zrušena tradiční součást projektu, a to soutěž mezi zapojenými městy o co největší počet pozorování živé přírody a zároveň i všechny plánované akce pro veřejnost. Přesto se počet zapojených účastníků významně nelišil oproti loňskému ročníku. Naopak počet pozorování strmě roste každým rokem bez ohledu na letošní vládní omezení. V době, kdy byl v ČR vyhlášen nouzový stav, probíhala intenzivní kampaň prezentující projekt CNC na sociálních sítích a webových stránkách. Nejen pro žáky základních a středních škol byla připravena online nabídka doprovodného programu (resp. návody a pracovní listy), která motivovala zájemce $\mathrm{k}$ intenzivnějšímu pozorování městské prrírody v bezprostředním okolí bydliště, na zahradách, ve vnitroblocích budov nebo na individuálních vycházkách do prrírody. 
Jak uvádí Duží a kol. (2019) i v případě CNC jde o projekt, který spojuje větší města ve společné aktivitě občanské vědy, a to jak celosvětově, tak v rámci České republiky. Projekt nabízí možnost dlouhodobé spolupráce s širokou komunitou. Další práce by se měly zaměřit na podrobnější studium motivace účastníků, ale také na možné změny nejen v jejich vědomostech, ale zároveň jejich postojích a chování. Do další studie je plánováno využití „škály propojení s prírodou" (Connectedness to nature scale - CNS) podle Mayer \& McPherson Frantz (2004).

\section{Poděkování}

Na tomto místě bychom chtěli poděkovat všem partnerům a účastníkům projektu City Nature Challenge: Praha, bez jejichž zapojení by se projekt netěšil takové úspěšnosti. Poděkování zároveň patří kolegům z Hvězdárny a planetária Brno, kteří se ujali prvního ročníku CNC v Brně.

Děkujeme i oběma recenzentům: J. Trojanovi (Univerzita Tomáše Bati ve Zlíně) a $M$. Adamovi (Fakulta logistiky a krizového řízení, Univerzita Tomáše Bati ve Zlíně) za kritické připomínky, které vedly k vylepšení rukopisu.

Předložená práce vznikla za finanční podpory Ministerstva kultury v rámci institucionálního financování dlouhodobého koncepčního rozvoje výzkumné organizace Národní muzeum (DKRVO 2019-2023/26.I.b, 00023272).

\section{Literatura}

Adamík P., Poledník L., Poledníková K., Romportl D., 2019: Mapping an elusive arboreal rodent: combining nocturnal acoustic surveys and citizen science data extends the known distribution of the edible dormouse (Glis glis) in the Czech Republic. - Mammalian Biology - Zeitschrift für Saugetierkunde 99: 12-18. https://doi.org/10.1016/j. mambio.2019.09.011

Admiraal J.F., Born van der R.J.G., Beringer A., Bonaiuto F., Cicero L., Hiedanpää J., Knights P., Knippenberg L., Molinario E., Musters C. J. M., Naukkarinen O., Polajnar Horvat K., Popa F., Smrekar A., Soininen T., Porras-Gomez C., Soethe N., Vivero Pol J.L., de Groot W., 2017: Motivations for committed nature conservation action in Europe. - Environmental Conservation 44, 2: 148-157. https://doi.org/10.1017/s037689291700008x

Adriaens T., Sutton-Croft M., Owen K., Brosens D., van Valkenburg J., Kilbey D. J., Groom Q. J., Ehmig C., Thürkow F., Van Hende P., Schneider K., 2015: Trying to engage the crowd in recording invasive alien species in Europe: experiences from two smartphone applications in northwest Europe. - Management of Biological Invasions 6, 2: 215-225. https://doi.org/10.3391/mbi.2015.6.2.12

Altrudi S., 2020: Connecting to nature through Ttech? The case of the iNaturalist app. Convergence: The International Journal of Research into New Media Technologies: 135485652093306. https://doi.org/10.1177/1354856520933064

Bäckstrand K., 2003: Civic Science for Sustainability: Reframing the Role of Experts, PolicyMakers and Citizens in Environmental Governance. - Global Environmental Politics 3, 4: 24-41. https://doi.org/10.1162/152638003322757916

Ballard, H.L., Robinson L.D., Young A., Pauly G.B., Higgins L.M., Johnson R.F., Tweddle J.C., 2017: Contributions to conservation outcomes by natural history museum-led citizen science: Examining evidence and next steps. - Biological Conservation 208: 87-97. https://doi. org/10.1016/j.biocon.2016.08.040

Bonney R., Cooper C.B., Dickinson J., Kelling S., Phillips T., Rosenberg K.V., Shirk J., 2009: Citizen Science: A Developing Tool for Expanding Science Knowledge and Scientific Literacy. - BioScience 59, 11: 977-984. https://doi.org/10.1525/bio.2009.59.11.9

Bonney R., Shirk J., Phillips T., Wiggins A., Ballard H., Miller-Rushing A., Parrish J., 2014: Next Steps for Citizen Science. - Science 343, 6178: 1436-1437. https://doi.org/10.1126/ science.1251554 
Boone M.E., Basille M., 2019: Using iNaturalist to contribute your nature observations to science. - EDIS 4: 5. https://doi.org/10.32473/edis-uw458-2019

Bruyere B., Rappe S., 2007: Identifying the Motivations of Environmental Volunteers. Journal of Environmental Planning and Management 50, 4: 503-516. https://doi. org/10.1080/09640560701402034

Cannon A.R., Chamberlain D.E., Toms M.P., Hatchwell B.J., Gaston K.J., 2005: Trends in the use of private gardens by wild birds in Great Britain 1995-2002. - Journal of Applied Ecology 42, 4: 659-671. https://doi.org/10.1111/j.1365-2664.2005.01050.x

Cepák J., Klvaňa P., Škopek J., Schröpfer L., Jelínek M., Hořák D., Formánek J., Zárybnický J., 2008: Atlas Migrace Ptáků České a Slovenské Republiky [Czech and Slovak Bird Migration Atlas]. - Praha: Avantium, 608 pp. [In Czech.]

Choy L.T., 2014: The Strengths and Weaknesses of Research Methodology: Comparison and Complimentary between Qualitative and Quantitative Approaches. - Journal of Humanities andSocialScience19,4:99-104.https://doi.org/10.9790/0837-194399104

Cohn J.P., 2008: Citizen Science: Can Volunteers Do Real Research? - BioScience 58, 3: 192197. https://doi.org/10.1641/b580303

Devictor V., Whittaker R.J., Beltrameet C., 2010: Beyond Scarcity: Citizen Science Programmes as Useful Tools for Conservation Biogeography. - Diversity and Distributions 16, 3 : 354-362. https://doi.org/10.1111/j.1472-4642.2009.00615.x

Devisch 0., Veestraeten D., 2013: From Sharing to Experimenting: How Mobile Technologies Are Helping Ordinary Citizens Regain Their Positions as Scientists. - Journal of Urban Technology 20, 2: 63-76. https://doi.org/10.1080/10630732.2013.769313

Diblíková L., Pipek P., Petrusek A., Svoboda J., Bílková J., Vermouzek Z., Procházka P., Petruskova T., 2018: Detailed Large-Scale Mapping of Geographical Variation of Yellowhammer Emberiza Citrinella Song Dialects in a Citizen Science Project. - Ibis 161, 2: 401-414. https://doi.org/10.1111/ibi.12621

Dickinson J.L., Shirk J., Bonter D., Bonney R., Crain R. L., Martin J., Phillips T., Purcell K., 2012: The current state of citizen science as a tool for ecological research and public engagement. - Frontiers in Ecology and the Environment 10, 6: 291-297. https://doi. org/10.1890/110236

Duží, B., Osman, R., Lehejček, J., Nováková, E., Taraba, P., Trojan, J., 2019: Exploring citizen science in post-socialist space: Uncovering its hidden character in the Czech Republic. - Moravian Geographical Reports 27, 4: 241-253. https://doi.org/10.2478/ mgr-2019-0019

Eitzel M.V., Oliver J., Santos-Lang C., Duerr R., Virapongse A., West S., Kyba C., Bowser A., Cooper C., Sforzi A., Metcalfe A., Harris E., Thiel M., Haklay M., Ponciano L., Roche J., Ceccaroni L., Shilling F., Dörler D., Jiang Q., 2017: Correction: Citizen Science Terminology Matters: Exploring Key Terms. - Citizen Science: Theory and Practice 2, 1: 2. https:// doi.org/10.5334/cstp.113

Falk J.H. (ed.), 2001: Free-choice science education: How we learn science outside of school. - New York: Teachers College Press, 216 pp.

Follett R., Strezov V., 2015: An Analysis of Citizen Science Based Research: Usage and Publication Patterns. - Plos One 10, 11: e0143687. https://doi.org/10.1371/journal. pone.0143687

Frigerio D., Pipek P., Kimmig S., Winter S., Melzheimer J., Diblíková L., Wachter B., Richter A., 2018: Citizen science and wildlife biology: Synergies and challenges. - Ethology 124, 6: 365-377. https://doi.org/10.1111/eth.12746

Frigerio D., Puehringer-Sturmayr V., Neuböck-Hubinger B., Gegendorfer G., Kotrschal K., Hirschenhauser K., 2019: Monitoring Public Awareness about the Endangered Northern Bald Ibis: a Case Study Involving Primary School Children as Citizen Scientists. PeerJ 7: e7569. https://doi.org/10.7717/peerj.7569 
Ganzevoort W., Riyan J.G., Born R., 2020: Understanding Citizens' Action for Nature: The Profile, Motivations and Experiences of Dutch Nature Volunteers. - Journal for Nature Conservation 55: 125824. https://doi.org/10.1016/j.jnc.2020.125824

Gardiner M.M., Allee L.L., Brown P.M.J, Losey J.E., Roy H.E., Rice Smyth R., 2012: Lessons from lady beetles: accuracy of monitoring data from US and UK Citizen-Science Programs. - Frontiers in Ecology and the Environment 10, 9: 471-476. https://doi. org/10.1890/110185

Gazdic M., Groom Q.J., 2019: iNaturalist is an unexploited source of plant-insect interaction data. - Biodiversity Information Science and Standards 3, e37303. https://doi. org/10.3897/biss.3.37303

Groom Q.J., Weatherdon L.V., Geijzendorffer I.R., 2016: Is citizen science an open science in the case of biodiversity observations? - Journal of Applied Ecology 54: 612-617. https:// doi.org/10.1111/1365-2664.12767

Haklay M., 2013: Citizen Science and Volunteered Geographic Information - overview and typology ofparticipation.-In: Sui D.Z.,Elwood S.,Goodchild M.F.(eds),2013:Crowdsourcing Geographic Knowledge: Volunteered Geographic Information (VGI) in Theory and Practice. 105-122. Berlin: Springer. https://doi.org/10.1007/978-94-007-4587-2_7

Harlin J., Kloetzer L., Patton D., Leonhard C., Leysin American School high school students, 2018: Turning students into citizen scientists. - In: Hecker S., Haklay M., Bowser A., Makuch Z. Vogel J., Bonn A., 2018: Citizen Science: Innovation in Open Science, Society and Policy. 410 - 428. London: UCL Press. https://doi.org/10.2307/j.ctv550cf2.35

Hernawati D., Chaidir D.M., Meylani V., 2020: The use of iNaturalist on learning courses of zoology vertebrates for prospective biology teachers. - Journal of Physics Conference Series 1440: 012064. https://doi.org/10.1088/1742-6596/1440/1/012064

Hobson E.A., Smith-Vidaurre G., Salinas-Melgoza A., 2017: History of nonnative Monk Parakeets in Mexico. - Plos One 12, 9: e0184771. https://doi.org/10.1371/journal. pone. 0184771

Hochmair H., Scheffrahn R., Basille M., Boone M., 2020: Evaluating the data quality of iNaturalist termite records. - Plos One 15, 5: e0226534. https://doi.org/10.1371/ journal.pone.0226534

Hsu C.-H., Chang Y.-M., Liu C.-C., 2019: Can Short-Term Citizen Science Training Increase Knowledge, Improve Attitudes, and Change Behavior to Protect Land Crabs? Sustainability 11, 14: 3918. https://doi.org/10.3390/su11143918

Johnson B., Mader A., Dasgupta R., Kumar P., 2020: Citizen science and invasive alien species: An analysis of citizen science initiatives using information and communications technology (ICT) to collect invasive alien species observations. - Global Ecology and Conservation 21: e00812. https://doi.org/10.1016/j.gecco.2019.e00812

Jordan R., Gray S., Sorensen A., Newman G., Mellor D., Hmelo-Silver C., LaDeau S., Biehler D., Crall A., 2016: Studying Citizen Science through Adaptive Management and Learning Feedbacks as Mechanisms for Improving Conservation. - Conservation Biology 30, 3: 487-495. https://doi.org/10.1111/cobi.12659

Kosmala M., Wiggins A., Swanson A., Simmons B., 2016: Assessing data quality in citizen science. - Frontiers in Ecology and the Environment 14: 551-560. https://doi. org/10.1002/fee.1436

Leong M., Trautwein M.D., 2019: A Citizen Science Approach to Evaluating US Cities for Biotic Homogenization. - PeerJ Preprints 7:e27472v1. https://doi.org/10.7287/peerj. preprints.27472v1

López Redondo M., Queiruga Dios M.A., Sáiz Manzanares M.C., Juez Navarro S., 2018: Citizen Science in School. - In: Costa M., Vázquez Dorrío J.B., Fernández Novell J.M. (eds): Hands-on science: Advancing Science, Improving Education. 194-198. Vigo: Universidade De Vigo.

Lukyanenko R., Parsons J., Wiersma Y.F., 2016: Emerging Problems of Data Quality in Citizen Science. - Conservation Biology 30, 3: 447-449. https://doi.org/10.1111/cobi.12706 
Macek I., Caltová P., 2019: City Nature Challenge. - Journal of the National Museum (Prague), Natural History Series 188: 163-166. https://doi.org/10.2478/jnmpnhs-2019-0010

Makuch K.E., Aczel M.R., 2020: Eco-Citizen Science for Social Good: Promoting Child WellBeing, Environmental Justice, and Inclusion. - Research on Social Work Practice 30, 2: 219-232. https://doi.org/10.1177/1049731519890404

Maund P., Irvine K., Lawson B., Steadman J., Risely K., Cunningham A., Davies Z., 2020: What Motivates the Masses: Understanding Why People Contribute to Conservation Citizen Science Projects. - Biological Conservation 246: 108587. https://doi.org/10.1016/j. biocon.2020.108587

Mayer F.S., McPherson Frantz C., 2004: The Connectedness to Nature Scale: A Measure of Individuals' Feeling in Community with Nature. - Journal of Environmental Psychology 24, 4: 503-515. https://doi.org/10.1016/j.jenvp.2004.10.001

McKinley D.C., Miller-Rushing A.J., Ballard H.L., Bonney R., Brown H., Cook-Patton S.C., Evans D.M., French R.A., Parrish J.K., Phillips T.B., Ryan S.F., Shanley L.A., Shirk J.L., Stepenuck K.F., Weltzin J.F., Wiggins A., Boyle O.D., Briggs R.D., Chapin S.F. III, Hewitt D.A., Preuss P.W., Soukup M.A., 2019: Citizen Science Can Improve Conservation Science, Natural Resource Management, and Environmental Protection. - Biological Conservation 208: 15-28. https://doi.org/10.1016/j.biocon.2016.05.015

Mitchell, N., Triska M., Liberatore A., Ashcroft L., Weatherill R., Longnecker N., 2017: Benefits and challenges of incorporating citizen science into university education. - PLoS ONE 12, 11: e0186285. https://doi.org/10.1371/journal.pone.0186285

Moore M.P., Lis C., Gherghel I., Martin R.A., 2019: Temperature Shapes the Costs, Benefits and Geographic Diversification of Sexual Coloration in a Dragonfly. - Ecology Letters 22, 3: 437-446. https://doi.org/10.1111/ele.13200

Njue N., Stenfert Kroese J., Gräf J., Jacobs S.R., Weeser B., Breuer L., Rufino M.C., 2019: Citizen Science in Hydrological Monitoring and Ecosystem Services Management: State of the Art and Future Prospects. - Science of The Total Environment 693: 133531. https://doi.org/10.1016/j.scitotenv.2019.07.337

Nugent J., 2008: Citizen Science: iNaturalist. -Science Scope 41, 7. https://doi.org/10.2505/4/ ss18_041_07_12

Ožana S., Burda M., Hykel M., Malina M., Prášek M., Bárta D., Dolný A., 2019: Dragonfly Hunter CZ: Mobile Application for Biological Species Recognition in Citizen Science. - Plos One 14, 1: e0210370. https://doi.org/10.1371/journal.pone.0210370

Pocock M.J.O., Chapman D.S., Sheppard, L.J., Roy H.E., 2014: Choosing and Using Citizen Science: a guide to when and how to use citizen science to monitor biodiversity and the environment. - Wallingford: Centre for Ecology \& Hydrology, $24 \mathrm{pp}$.

Pocock M.J.O., Tweddle J.C., Savage J., Robinson L.D., Roy H.E., 2017: The Diversity and Evolution of Ecological and Environmental Citizen Science. - Plos One 12, 4: e0172579. https://doi.org/10.1371/journal.pone.0172579

Schade S., Kotsev A., Cardoso A.C., Tsiamis K., Gervasini E., Spinelli F. A., Mitton I., Sgnaolin R., 2019: Aliens in Europe. An open approach to involve more people in invasive species detection. - Computers, Environment and Urban Systems 78: 101384. https://doi. org/10.1016/j.compenvurbsys.2019.101384

Silvertown J., 2009: A new dawn for citizen science. - Trends in Ecology \& Evolution 24, 9: 467-471. https://doi.org/10.1016/j.tree.2009.03.017

Stelle L.L., 2017: Using Citizen Science to Study the Impact of Vessel Traffic on Marine Mammal Populations. - In: Cigliano J.A., Ballard H.L. (eds): Citizen Science for Coastal and Marine Conservation.77-103.New York:Routledge. https://doi.org/10.4324/9781315638966-5

Sutherland W., Roy D.B., Amano T., 2015: An agenda for the future of biological recording for ecological monitoring and citizen science. - Biological Journal of the Linnean Society 115: 779-784. https://doi.org/10.1111/bij.12576 
Trojan J., Schade S., Lemmens R., Frantál B., 2019: Citizen science as a new approach in Geography and beyond: Review and reflections. - Moravian Geographical Reports 27, 4: 254-264. https://doi.org/10.2478/mgr-2019-0020

Troudet J., Grandcolas P., Blin A., Vignes-Lebbe R., Legendre F., 2017: Taxonomic bias in biodiversity data and societal preferences. - Scientific Reports 7: 1-14. https://doi. org/10.1038/s41598-017-09084-6

Tuckett A.G., Freeman A., Hetherington S., Gardiner P.A., King A.C., 2018: Older Adults Using Our Voice Citizen Science to Create Change in Their Neighborhood Environment. International Journal of Environmental Research and Public Health 15, 12: 2685. https:// doi.org/10.3390/ijerph15122685

Tweddle J.C., Robinson L.D., Pocock M.J.O., Roy H.E., 2012: Guide to Citizen Science: Developing, Implementing, and Evaluating Citizen Science to Study Biodiversity and the Environment in the UK. - Wallingford: NERC/Centre for Ecology and Hydrology, 29 pp.

Unger S., Rollins M., Tietz A., Dumais H., 2020: iNaturalist as an Engaging Tool for Identifying Organisms in Outdoor Activities. - Journal of Biological Education: 1-11. https://doi.org /10.1080/00219266.2020.1739114

Whitaker M.R.L., Jiron J., Maass B., 2014: Developing Mobile Tools for Biodiversity Informatics and Natural History Education. - Journal of Natural History Education and Experience 8: 29-33.

Wilson J.S., Pan A.D., General D.E.M., Koch J.B., 2020: More Eyes on the Prize: an observation of a very rare, threatened species of Philippine Bumble Bee, Bombus Irisanensis, on iNaturalist and the Importance of Citizen Science in Conservation Biology. - Journal of Insect Conservation 24, 4: 727-729. https://doi.org/10.1007/s10841-020-00233-3

\section{Internetové zdroje}

CNC 2020 (City Nature Challenge 2020): https://citynaturechallenge.org/ [Accessed on 28 May 2020.]

ESCA 2020 (European Citizen Science Association; dokumenty): https://ecsa.citizen-science. net/documents [Accessed on 28 May 2020.]

RVP G 2016 (Rámcový vzdělávací program pro gymnázia): http://www.nuv.cz/file/159_1_1/ [Accessed on 28 May 2020.]

\section{Summary}

Recently, citizen science projects have been used more frequently, especially in the natural sciences. The present study deals with the potentialities and significance of these projects. It also presents and discusses the results of a questionnaire survey from participants in the City Nature Challenge: Prague project, and users of the iNaturalist mobile application. Obtained data indicate the motivation of participants is an important phenomenon for the success of citizen science projects, and outline changes in the behavior and attitudes of this project's participants. An important output is the finding that more than half of the participants cited the use of the iNaturalist mobile application as the reason for more frequent trips into nature. The authors encourage further involvement of age groups up to 30 years in citizen science, and the study of both internal and external motivations of participants, as well as changes in their acquired knowledge, attitudes and behavior. 